\title{
Application of the Shear Press to Determine The Degree of Maturity of Pigeonpeas
}

\author{
F. Sánchez-Nieva ${ }^{1}$
}

INTRODUCTION

The quality of canned and frozen pigeonpeas depends to a large extent on the degree of maturity of the peas processed. Sánchez-Nieva $(1)^{2}$ showed that various quality criteria, such as drained weight, volume and viscosity of the brine, color and turbidity of the brine, and uniformity of color with respect to the predominance of the green pigment in the canned product, depend on the maturity of the pigeonpeas processed. The quality of frozen peas was likewise found to depend to a large degree on maturity. Fully mature green pigeonpeas with an alcohol-insoluble solid content of about 27 percent gave a higher quality product when frozen than the more tender or overripe peas (2).

Sánchez-Nieva et al. ( $(3)$ found that, when pigeonpeas mature, there is an increase in the starch, alcohol-insoluble solids, and total-solids contents, and in the specific gravity. A high correlation was obtained between the intensity of the green pigment and starch, alcohol-insoluble solids, total solids, and specific gravity. The determination of most of these maturity indices is time-consuming and therefore they do not lend themselves well to establishing quality control in the cannery. A more rapid method for measuring the maturity of pigeonpeas is therefore highly desirable.

The use of the shear press to measure food quality was first described by Kramer et al. (4). The literature contains several reports on the use of the shear press to measure the quality of foods. Weckel et al. (5) established an interrelationship between tenderometer readings, shear-press values, and alcohol-insoluble solids. Kramer et al. (6) found shear-press values equal in precision and accuracy to the tenderometer, and superior to the texturemeter for measuring the quality of peas. The shear press was reported by Kramer (7) to be useful for measuring the maturity of raw peas, lima beans, and southern beans; the firmness of raw or canned apple slices, beets, sphaghetti, chicken, beef, and shrimp; the fibrousness of asparagus and string beans; and the succulence of sweet corn and apples. Wiley et al. (8) used the shear press to measure the quality of asparagus, and Backinger et al. (9) used a

1 Technical Director, Food Technology Laboratory, Agricultural Experiment Station, University of Puerto Rico, Río Piedras, P.R. The author wishes to acknowledge the valuable assistance of Miss N. Diaz and Mr. I. Hernández, Research Assistant and Assistant Chemical Engincer, respectively, of the Food Technology Laboratory for analyzing the samples used in this study.

${ }^{2}$ Italic numbers in parentheses refer to Literature Cited, p. 216. 
modified shear press for electrical indication and recording, as described by Decker et al. (10), to measure the fibrousness of this vegetable. The shear press was used by Shannon et al. (11) to measure the tenderness of chicken meat.

The objective of this work was to study the application of the shear press to measurement of the maturity of pigeonpeas by correlating shearpress values with other indices, such as alcohol-insoluble solids, totalsolids content, and percentage of starch.

\section{MATERIALS AND METHODS}

Pigeonpeas of the Kaki selection were harvested at different stages of development ranging from very tender green to overripe yellow peas. A representative sample of shelled peas was taken for analysis. Total solids, alcohol-insoluble solids, and starch were determined by the methods described by Sánchez et al. (3). The percentage of green and yellow peas in the sample was determined by count.

A Lee-Kramer electrical recording and indicating shear press was used in these studies. A 5,000-pound proving ring was used in all determinations. Since the press was provided with a multiple selector switch to select the range desired, most of the readings were taken in the 2,000-pound range. The plunger was adjusted to move at $1.466 \mathrm{~mm}$./second. A standard shear cell was used for all determinations. To make a measurement, the pigeonpeas were poured into the cell until it was packed full, and the upper surface of the peas was even with the top of the sides of the cell. The time-force curve for each sample was recorded and the maximum pressure applied was read directly from the chart.

\section{RESULTS}

Shear-press values for the different samples analyzed, with the corresponding values for the alcohol-insoluble solids and total-solids content, for starch and percentage of yellow peas, are given in table 1. The correlation between shear-press values and the corresponding objective maturity indices was studied. Correlation coefficients for the different indices measured are given in table 2.

Regression equations for each objective index measured and shear-press values are given in table 2 , with the corresponding sample correlation coefficients. A test for significance for both the correlation and regression coefficients shows significance at the 1-percent level for all the characteristics measured. These results show that the shear press can be used with accuracy to measure the maturity of pigeonpeas. Furthermore, from the regression equations it is possible to calculate the expected values for the 
starch, alcohol-insoluble solids, and total-solids content, and the percentage of yellow peas for any sample from the corresponding shear-press reading. Expected values for all these indices calculated from the corre-

TABLE 1.-Average shear-press reading with the corresponding values for alcohol-insoluble solids, starch, and total solids content, and

percentage of yellow pigeonpeas in the sample

\begin{tabular}{|c|c|c|c|c|}
\hline $\begin{array}{c}\text { Shear-press reading } \\
\text { (pounds) }\end{array}$ & $\begin{array}{c}\text { Alcohol-insoluble } \\
\text { solids }\end{array}$ & Starch & Total solids & $\begin{array}{c}\text { Yellow peas by } \\
\text { count }\end{array}$ \\
\hline & Percent & Percenl & Per cent & Percent \\
\hline 1,650 & 26.9 & 17.9 & 33.0 & 17.7 \\
\hline 1,500 & 23.8 & 17.2 & 28.8 & 13.5 \\
\hline 1,470 & 24.4 & 16.0 & 29.8 & 11.5 \\
\hline 1,000 & 25.0 & 13.8 & 31.6 & 4.6 \\
\hline 1,080 & 25.1 & 16.3 & 31.9 & 10.8 \\
\hline 1,650 & 27.7 & 18.6 & 34.2 & 13.4 \\
\hline 1,100 & 25.1 & 15.5 & 33.1 & 14.5 \\
\hline 1,100 & 26.8 & 17.0 & 32.4 & 12.9 \\
\hline 1,380 & 30.0 & 20.4 & 35.8 & 17.1 \\
\hline 1,630 & 30.0 & 10.7 & 36.8 & 17.8 \\
\hline 1,320 & 27.9 & 18.9 & 34.2 & 20.6 \\
\hline 2,150 & 28.4 & 17.8 & 34.2 & 21.0 \\
\hline 1,850 & 28.1 & 18.9 & 34.1 & 14.6 \\
\hline 1,750 & 28.8 & 19.6 & 34.6 & 14.2 \\
\hline 2,050 & 28.5 & 18.5 & 35.0 & 27.4 \\
\hline 2,160 & 28.5 & 19.0 & 36.4 & 29.0 \\
\hline 2,170 & 30.0 & 19.6 & 36.3 & 26.7 \\
\hline 1,650 & 27.3 & 17.3 & 27.3 & 8.7 \\
\hline 1,420 & 24.3 & 14.4 & 24.0 & 5.6 \\
\hline 1,500 & 26.5 & 17.5 & 25.1 & 5.7 \\
\hline 840 & 25.2 & 15.4 & 30.6 & 11.9 \\
\hline 730 & 25.2 & 13.6 & 27.4 & 4.3 \\
\hline 1,020 & 24.9 & 15.2 & 29.8 & 5.9 \\
\hline 610 & 19.3 & 10.9 & 25.6 & .8 \\
\hline 820 & 21.4 & 12.0 & 24.8 & 6.1 \\
\hline 760 & 22.3 & 12.5 & 28.2 & 2.4 \\
\hline 590 & 10.3 & 9.4 & 25.9 & 1.2 \\
\hline 620 & 22.2 & 10.5 & 26.5 & .6 \\
\hline 780 & 22.7 & 12.8 & 28.5 & 2.3 \\
\hline 680 & 22.7 & 13.4 & 29.5 & 2.2 \\
\hline 660 & 21.8 & 12.4 & 26.7 & 1.1 \\
\hline 840 & 23.8 & 14.5 & 29.0 & 7.6 \\
\hline 1,850 & 29.3 & 19.3 & 36.3 & 15.4 \\
\hline 2,000 & 30.3 & 20.2 & 38.6 & 17.8 \\
\hline
\end{tabular}

sponding regression equations for shear-press readings ranging from $\mathbf{5 0 0}$ to 2,000 pounds, are given in table 3 .

The shear press was found to afford a rapid means of determining the 
maturity of pigeonpeas. Since the time required to make a measurement with the shear press is only a few minutes, this instrument can be used to control the quality of pigeonpeas during canning or freezing. Furthermore,

TABLE 2.-Correlation between shear-press readings and objective indices derived from table 1

\begin{tabular}{|c|c|c|c|c|c|c|}
\hline \multirow{2}{*}{$\begin{array}{l}\text { Objective index } \\
\text { (percent) }\end{array}$} & \multirow[b]{2}{*}{ Regression equation } & \multicolumn{2}{|c|}{$\begin{array}{l}\text { Correlation } \\
\text { coefficient }\end{array}$} & \multicolumn{3}{|c|}{$\begin{array}{l}\text { Regression } \\
\text { coefficient }\end{array}$} \\
\hline & & $\begin{array}{l}\text { Calcu- } \\
\text { lated }\end{array}$ & $\begin{array}{c}\text { At 1- } \\
\text { percent } \\
\text { level }\end{array}$ & $b$ & $\begin{array}{c}\text { Calcu- } \\
\text { lated } \\
\text { f } \\
\text { value }\end{array}$ & $\begin{array}{c}t \text {-value } \\
\text { at 1- } \\
\text { percent } \\
\text { level }\end{array}$ \\
\hline $\begin{array}{l}\text { Total solids } \\
\text { Starch } \\
\text { Alcohol-insoluble } \\
\text { solids } \\
\text { Yellow peas }\end{array}$ & $\begin{array}{l}Y_{1}=0.0051 \mathrm{X}+25.3 \\
Y_{2}=0.0052 \mathrm{X}+9.3 \\
Y_{3}=0.0051 \mathrm{X}+19.1 \\
Y_{4}=0.0137-6.8\end{array}$ & $\begin{array}{r}0.768 \\
.757 \\
.852 \\
.906\end{array}$ & $\begin{array}{r}0.478 \\
.437 \\
\\
.437 \\
.443\end{array}$ & $\begin{array}{r}0.0051 \\
.0052 \\
.0051 \\
.0137\end{array} \mid$ & $\left|\begin{array}{r}5.932 \\
6.540 \\
8.279 \\
11.877\end{array}\right|$ & $\begin{array}{l}2.763 \\
2.728 \\
\\
2.728 \\
2.733\end{array}$ \\
\hline
\end{tabular}

TABLE 3.-Expected values for tolal solids, percentage starch, alcohol-insoluble solids, and percentage yellow pigeonpeas for a range of shear-press values from 500 to $2,000 \mathrm{lb}$.

\begin{tabular}{c|c|c|c|c}
\hline $\begin{array}{c}\text { Shear-press reading } \\
\text { (pounds) }\end{array}$ & Total solids $Y_{1}$ & Starch $Y_{2}$ & $\begin{array}{c}\text { Alcohol.insoluble } \\
\text { solids } Y_{3}\end{array}$ & Yellow peas $Y_{4}$ \\
\cline { 2 - 3 } & Percent & Percent & Percent & Percent \\
500 & 27.9 & 11.9 & 21.6 & 8.2 \\
600 & 28.4 & 12.4 & 22.1 & 10.2 \\
700 & 28.9 & 12.9 & 22.7 & 11.0 \\
800 & 29.5 & 13.5 & 23.2 & 12.3 \\
900 & 30.0 & 14.0 & 23.7 & 13.7 \\
1,000 & 30.5 & 14.5 & 24.2 & 15.1 \\
1,100 & 31.0 & 15.0 & 24.7 & 16.4 \\
1,200 & 31.5 & 15.6 & 25.2 & 17.8 \\
1,300 & 32.0 & 16.1 & 25.7 & 19.2 \\
1,400 & 32.5 & 16.6 & 26.2 & 20.5 \\
1,500 & 33.1 & 17.1 & 26.7 & 21.9 \\
1,600 & 33.6 & 17.6 & 27.2 & 23.3 \\
1,700 & 34.1 & 18.2 & 27.7 & 24.6 \\
1,800 & 34.6 & 18.7 & 28.2 & 26.0 \\
1,900 & 35.1 & 19.2 & 28.7 & 27.3 \\
2,000 & 35.6 & 19.7 & 29.2 & 28.7 \\
\hline
\end{tabular}

since, as shown by Sánchez (1), the grade of the canned product can be predicted from the alcohol-insoluble solid content, or from the number of yellow peas present, and the expected grade of the lot being processed can be predicted from the shear-press value measured on a sample truly representative of the lot. 


\section{SUMMARY}

The Lee-Kramer shear press has been found to afford a rapid means of measuring the maturity of pigeonpeas. The high correlation coefficients between shear-press readings and starch, alcohol-insoluble solids, and total-solids content, and with the percentage of yellow pigeonpeas, indicate that the shear press can be used with accuracy to measure the maturity of pigeonpeas. Regression equations can be used to calculate the values for the objective indices from the corresponding shear-press readings.

\section{RESUMEN}

Se determinó que la prensa Lee Kramer puede usarse para medir rápidamente la madurez del gandur. Los coeficientes de alta correlación entre los índices de madurez y el contenido de almidón, los sólidos insolubles en alcohol y sólidos totales, y el porcentaje de granos amarillos indican que la prensa Lee Kramer puede usarse para medir la madurez del gandur con precisión. Se demostró que del valor obtenido en la prensa Lee Kramer, mediante el uso de las ecuaciones de regresión, se pueden calcular con precisión los valores correspondientes para los índices de madurez antes indicados.

\section{LITERATURE CITED}

1. Sánchez-Nieva, F., The influence of maturity on the quality of canned pigeonpeas, J. Agr. Univ. P.R. 45 (4) 217-31, 1961.

2. Sánchez-Nieva, F., González, M. A., and Benero, J. R., The freezing of pigeonpeas for market, J. Agr. Univ. P.R. 45 (4) 205-16, 1961.

3. Sánchez-Nieva, F., Cancel M. M., and Benero, J. R., Maturity indices for pigeonpeas, J. Agr. Univ. P.R. 44 (2) 60-9, 1960.

4. Kramer, A., Burkhardt, G. J., and Rogers, H. P., The shear press-a device for measuring food quality, The Canner 112 (5) 34-6, 40, 1951.

5. Weckel, K. G., Rodriguez, C. R., and Kuesel, D. C., Interrelation between tenderometer, shear press, and alcohol insoluble solids, Food Packer 36 (10) 24-6, 1954.

6. Kramer, A., and Aamlid, K., The shear press, an instrument for measuring the quality of foods, III, Application to peas, Proc. Amer. Soc. Hort. Sri. 61 417-23, 1953.

7. Kramer, A., Food texture rapidly gaged with versatile shear press, Food Engin. 29 (5) 57, 1957.

8. Wiley, R. C., Elehwany, N., Kramer, A., and Hager, F. J., Shear press, an instrument for measuring the quality of food, IV, Application to asparagus, Food Technol. 10 (9) 439-43, 1956.

9. Backinger, G. T., Kramer, A., Decker, R. W., and Sidwell, A. P., Application of work measurement to the determination of fibrousness in asparagus, Food Technol. 11 (11) 583-5, 1957.

10. Decker, R. W., Yeatman, J. N., Kramer, A., and Sidwell, A. P., Modification of the shear press for electrical indicating and recording, Food Technol. 11 (6) 343-7, 1957.

11. Shannon, W. G., Marion, W. W., and Stadelman, W. J., Effect of temperature and time of scalding on the tenderness of breast meat of chicken, Food Technol. 11 (5) 284-6, 1957. 